\title{
A note on the nutritive value of dry ripe plantain. peels as a replacement of maize for goats
}

\author{
E.M. Aregheore* \\ Department of Agricultural Sciences, Animal Production Unit, \\ College of Education \\ P.M.B. 1251, Warri, Delta State, Nigeria
}

(Received 19 August 1997; accepted 14 January 1998)

\section{ABSTRACT}

Twenty-four West African Dwarf (WAD) goats with a mean liveweight of $2.88 \pm 0.08 \mathrm{~kg}, 9-12$ months old were randomly divided according to sex and weight into 4 groups of 6 animals each. Plantain peels (DMRPP) replaced maize at 0, 60, 80 and $100 \%$ levels in the concentrates that were fed ad libitum for 84 days. Voluntary concentrate intakes decreased linearly, but not at a significant level $(\mathrm{P}>0.05)$ as the substitution of maize with plantain peels increased in the diet. Forage intake among the four groups remained within the same limits. Daily liveweight gains were higher $(\mathrm{P}<0.05)$ at the 60 and $80 \%$ replacement levels with values of 73 and 74 $\mathrm{g} /$ head/day, respectively, compared to 70 and $68 \mathrm{~g} /$ head/day for the 0 and $100 \%$ replacement levels. There was no significant difference $(\mathrm{P}>0.05)$ between diets 1 $(0 \%$, only maize $)$ and $4(100 \%$, only plantain peels) in daily liveweight gains. Dry matter, starch and energy were digested better $(\mathrm{P}<0.05)$ in diet 1 but crude protein and crude fibre fractions were digested worse $(\mathrm{P}<0.05)$ than in the other diets. Cost/ $\mathrm{kg}$ of diet and of liveweight gain declined in descending order of maize replacement with DMRPP. Results of the trial indicated that DMRPP is acceptable and can substitute for maize for goats without adverse effects on growth and animal performance. Plantain peels also proved to be an economical source of carbohydrate in goat nutrition, especially in areas where plantain abounds.

KEY WORDS: maize, dry ripe plantain peels, nutrition, serum glucose, plasma urea-N, goats

* Present address for correspondence: Institute for Animal Production in the Tropics and Subtropics 480, Hohenheim University, D-70593 Stuttgart, Germany 


\section{INTRODUCTION}

Plantain (Musa sapientum Var. Paradisiaca, L.) is grown in many tropical countries as an important source of carbohydrate for humans (Oycnuga, 1968; Ketiku, 1973; Swennen, 1990). Several researchers have used different parts of plantain/ banana in the nutrition of ruminants (Ffoulkes et al., 1978; Geoffroy and Despois, 1978; Ohide et al., 1979; Pezo and Fanola, 1980; Poyyamozhi and Kadirvel, 1986; Subramanian et al., 1988), however, little data are available on the utilization of the peels as a carbohydrate source in ruminant nutrition (Aregheore and Aluyi, 1989). While it is not advisable to feed the pulp, the peels could be processed and used as a cheap source of carbohydrate in the diets of sheep and goats (Oyenuga, 1968; Ankrah, 1974).

Ripe plantain pecls are low in crude fibre, but rich in mineral matter, carbohydrate and certain vitamins (Ketiku, 1973; Ankrah, 1974), therefore, if well preserved and processed they can be incorporated into livestock rations (Aregheore, 1994).

The objectives of this work are to 1 . determine the effect of processing on the acceptance of ripe peels, 2 . determine the optimal level at which ripe processed peels could be used to replace maize in the concentrate supplements of goats in confinement and 3 . determine the economics of production with such concentrates in small ruminant (goats) rations.

\section{MATERIAL AND METHODS}

Plantain peels were gathered from different restaurants until a large enough quantity was assembled. The peels were spread on a concrete floor and dried on a continuous basis in the sun for at least 3 weeks to a constant weight and colour, and later

TABLE 1

Nutrient composition of maize, plantain peels and forage - Guinea grass (Panicum maxima)

\begin{tabular}{lccc}
\hline & \multicolumn{3}{c}{ Feeds } \\
\cline { 2 - 4 } Nutrient,s \% & maize & plantain peels & forage \\
\hline Dry matter & 90.38 & 64.14 & 55.62 \\
In DM & & & \\
$\quad$ crude protein & 9.00 & 9.04 & 12.80 \\
crude fibre & 2.30 & 6.38 & 34.80 \\
ether extract & 3.82 & 5.58 & 1.06 \\
ash & 3.62 & 7.19 & 3.58 \\
N-free extractives & 81.26 & 71.81 & 46.76 \\
starch & 70.30 & 61.81 & 25.87 \\
Gross energy, MJ/kg & 17.06 & 15.56 & 12.58 \\
\hline
\end{tabular}


TABLE 2

Ingredients and composition of the diets, \%, air dry basis

\section{Diets}

\begin{tabular}{lrrrr} 
& \multicolumn{1}{c}{1} & 2 & 3 & 4 \\
\hline Maize, milled & 50.00 & 20.00 & 10.00 & 00.00 \\
Plantain peels, milled & 00.00 & 30.00 & 40.00 & 50.00 \\
Wheat offals & 10.00 & 10.00 & 10.00 & 10.00 \\
Brewers'dried grains & 36.45 & 36.45 & 36.45 & 36.45 \\
Urea (46\%-N) & 2.80 & 2.80 & 2.80 & 2.80 \\
Mineral-vitamin mixture* & 0.50 & 0.50 & 0.50 & 0.50 \\
Salt & 0.25 & 0.25 & 0.25 & 0.25 \\
Total & 100.00 & 100.00 & 100.00 & 100.00 \\
\hline
\end{tabular}

* Minovit super by Intervet International, BV Boxneer, Holland. Composition per $1000 \mathrm{~g}^{-1}$; vitamin a, $7500000 \mathrm{IU}$; vitamin $\mathrm{D}_{3}, 1500000 \mathrm{IU}$; vitamin $\mathrm{B}_{1}, 1000 \mathrm{mg}$; vitamin $\mathrm{B}_{2}, 2750 \mathrm{mg}$; vitamin $\mathrm{B}_{12}, 5 \mathrm{mg}$; D-calcium panthethenate, $5000 \mathrm{mg}$; vitamin $\mathrm{E}, 2500 \mathrm{mg}$; vitamin $\mathrm{K}, 1500 \mathrm{mg}$, niacin, $12500 \mathrm{mg}$; choline chloride, $60000 \mathrm{mg}$; ethoxyquin. $5000 \mathrm{mg}$; manganese oxide, $16130 \mathrm{mg}$; potassium iodide, $353 \mathrm{mg}$; cobalt sulphate, $286 \mathrm{mg}$; zinc oxide, 125000; copper oxide, 1283; ferro-carbonate, $20323 \mathrm{mg}$

milled with a Willey mill. The milled product (referred to as dried milled ripe plantain peels, DMRPP) was used with other ingredients in the diets. DMRPP were incorporated at $0,60,80$ and $100 \%$ levels of the maize portion of concentrate diets.

Other feedstuffs and ingredients used were maize, wheat offals, brewers' dried grains, urea and a mineral-vitamin supplement. In diet $1(0 \%)$ maize was the major carbohydrate source, while in dicts 2,3 and 4 the maize portions were replaced with plantain peels at 60,80 and $100 \%$. The rations were formulated to be isonitrogenous (Tables 1 and 2).

Twenty-four West African Dwarf goats, 9-12 months old with an average liveweight of $12.88 \pm 0.08 \mathrm{~kg}$, were isolated for two months for observation against any disease manifestation. They were dewormed with thiabendazol and sprayed every fourth night with acaricide against tick infestation, and vaccinated against pests des petits ruminant (PPR) which is prevalent in the months of November and December when the experiment was conducted. The goats were allotted randomly according to age, sex and weight into the four diets which were fed ad libitum for 84 days with free access to fresh clean water. Six goats in each group made up the 6 replicates of the completely randomised design experiment. The goats were housed in groups according to treatments and all management practices of feeding and watering were observed. Daily refusals were collected and weighed. The concentrate ration was supplemented with chopped forage made up of guinea grass (Panicum maxima, Jacq.) and fed at 9.00 and $16.30 \mathrm{~h}$. Average body weights at the beginning and at the end of the experiment were used for growth rate and feed efficiency evaluations. 
On the 30 th day of the trial, blood samples were collected $4 \mathrm{~h}$ after the morning feeding from the jugular vein, and analysed for glucose and urea- $\mathrm{N}$.

At the end of the growth trial, 4 goats of similar body weight were harnessed for 7 days faecal collection. Faeces were dried in a forced-draught oven at $70^{\circ} \mathrm{C}$ for $24 \mathrm{~h}$. The samples of concentrates, forage and faeces were analysed for chemical composition.

\section{Analytical procedures}

AOAC (1980) methods were used for the determination of dry matter (DM) and nutrient contents of maize, plantain peels, concentrate and faeces. Determination of the gross energy in the maize, plantain peels, concentrates and faeces was done by Adiabatic Bomb Calorimetry. From these determinations digestibility values were calculated by the methods for mixed diets outlined by Crampton (1956) as follows:

$$
\mathrm{S}=100 \mathrm{~T}-\mathrm{B} / \mathrm{S}+\mathrm{B}
$$

where:

$\mathrm{S}=$ digestibility of concentrate supplement

$\mathrm{B}=$ digestibility of basal diet - forage

$\mathrm{T}=$ digestibility of the mixed diet, i.e. concentrate supplement and forage basal diet $\mathrm{S}=$ proportion of concentrate supplement in the mixed diet.

Blood glucose was determined according to Sigma Chemical Company (1976), and urea- $\mathrm{N}$ according to Gentzkow and Masen (1942). Quantitative analyses of starch in plantain peels, maize, concentrates, forage and faeces were carried out using the method of MacRae and Armstrong (1968).

All obtained data were subjected to analyses of variance, the procedures of Steel and Torrie (1960), and where significant differences occurred, Bonferroni t-statistics, were used for comparison among treatment means (Gill, 1978).

TABLE 3

Chemical composition of the diets, \% air dry basis

\begin{tabular}{lrrrr}
\hline & \multicolumn{4}{c}{ Diets } \\
\cline { 2 - 5 } Nutriens & 1 & \multicolumn{1}{c}{2} & \multicolumn{1}{c}{3} & \multicolumn{1}{c}{4} \\
\hline Dry matter & 89.54 & 87.12 & 87.36 & 87.48 \\
In DM & & & & \\
$\quad$ crude protein & 13.14 & 13.23 & 13.28 & 13.30 \\
crude fibre & 6.80 & 8.20 & 8.80 & 9.10 \\
ether extract & 4.40 & 4.45 & 4.45 & 4.38 \\
ash & 5.76 & 6.30 & 6.50 & 6.60 \\
N-free extractives & 69.90 & 67.82 & 66.97 & 66.62 \\
$\quad$ starch & 68.52 & 67.68 & 67.09 & 65.32 \\
Gross energy MJ/kg & 19.32 & 18.86 & 17.65 & 16.10 \\
\hline
\end{tabular}




\section{RESULTS AND DISCUSSION}

The nutritive value of the maize used did not differ from the values reported by Oyenuga (1968) and Arcgheore et al. (1988). Except for crude protein which was higher, other nutrient values of DMRPP were similar to those reported earlier by Ketiku (1973) and Ankrah (1974). Treatment means for all performance characteristics and blood metabolites are presented in Table 4.

Voluntary concentrate intake decreased linearly, but not at a significant level $(P>0.05)$ with increases the levels of plantain peels in the concentrates. Forage intake in all groups was similar. Total voluntary feed intakes (concentrate + forage) did not differ significantly ( $\mathrm{P}>0.05)$ among the groups.

Feeding the $100 \%$ DMRPP was found equivalent to that of the $100 \%$ maize $(0 \%$ plantain peels) diet. The observed decrease in concentrate intake with increases in DMRPP may likely be due to an increased digestible energy (DE) intake from those diets (McCullogh, 1970). It has been observed that animals fed ad libitum attempt to equalize their DE intake (Montgomery and Baumgardt, 1965).

There were no significant differences between diets 1 and 4 in daily liveweight gain $(\mathrm{P}>0.05)$ but the liveweight gains of goats fed rations 2 and 3 were better than diet 4. Body weight gains were low, however, the range of gain seems to be normal with the West African Dwarf goats owing to their small size (Williamson and Payne, 1978; Aregheore, 1994). Feed efficiency followed the pattern of concentrate intake and daily liveweight gains.

TABLE 4

Weight gain, feed intake, feed efficiency, blood indices and production cost

\begin{tabular}{|c|c|c|c|c|}
\hline \multirow[b]{2}{*}{ Parameters } & \multicolumn{4}{|c|}{ Diets } \\
\hline & 1 & 2 & 3 & 4 \\
\hline Initial body weight, $\mathrm{kg}$ & $12.80 \pm 0.10$ & $12.84 \pm 0.06$ & $12.82=0.07$ & $12.85 \pm 0.08$ \\
\hline Final body weight, $\mathrm{kg}$ & $18.48 \pm 0.20$ & $18.97 \pm 0.82$ & $19.04 \pm 0.91$ & $18.56 \pm 0.86$ \\
\hline Body weight gain, g/day & $70^{\mathrm{sll}}$ & $73^{i}$ & $74 a$ & $68 \mathrm{~b}^{\mathrm{c}}$ \\
\hline Forage intake, $\mathrm{kg}^{\prime}$ & 0.34 & 0.35 & 0.34 & 0.36 \\
\hline Concentrate intake, $\mathrm{kg}^{2}$ & $0.84:$ & $0.83^{\mathrm{ab}}$ & $0.82^{\text {at }}$ & $0.79^{\mathrm{bc}}$ \\
\hline Total feed intake, $\mathrm{kg}$ & 1.18 & 1.18 & 1.16 & 1.15 \\
\hline Feed efficiency, feed/gain & $16.86^{\mathrm{h}}$ & $16.16^{\mathrm{ub}}$ & $15.68^{\mathrm{a}}$ & $16.91^{\mathrm{b}}$ \\
\hline Blood glucose, $\mathrm{mg} / 100 \mathrm{ml}$ & $76.98 \pm 1.08^{\mathrm{it}}$ & $73.09 \pm 2.00^{\mathrm{a}}$ & $69.18 \pm 1.96^{\mathrm{h}}$ & $64.21 \pm 0.18^{\circ}$ \\
\hline Blood urea-N, mg/100ml & $33.92 \pm 3.45^{4}$ & $35.09 \pm 0.08^{\mathrm{b}}$ & $35.18 \pm 3.08^{h}$ & $34.09 \pm 1.08^{\mathrm{ab}}$ \\
\hline Cost $/ \mathrm{kg}$ ration, $\mathrm{N}^{*}$ & 3.08( & 1.04 & $0.96(31)$ & $0.88(29)$ \\
\hline Cost $/ \mathrm{kg} \mathrm{LWG}, \mathrm{N}^{*}$ & 17.00( & $15.91(c$ & $15.51(91)$ & $14.00(82)$ \\
\hline
\end{tabular}

$\mathrm{a}, \mathrm{b}, \mathrm{c} \cdots \mathrm{P}<0.05$

* values in round parentheses are in $\mathrm{N}=$ Naira, Nigerian currency (USD $1=24 \mathrm{~N}$ ) and those on square parentheses are in relative ratio to diet 1 as per cent 
TABLE 5

Nutrients digestibility by goats, $\%$

\begin{tabular}{lcccc}
\hline & \multicolumn{5}{c}{ Diets } \\
\cline { 2 - 5 } Components & 1 & 2 & 3 & 4 \\
\hline Dry matter & $86.3 \pm 1.20^{\mathrm{a}}$ & $83.1 \pm 1.08^{\mathrm{b}}$ & $83.2 \pm 0.98^{\mathrm{h}}$ & $81.0 \pm 1.06^{\mathrm{c}}$ \\
Crude protein & $86.9 \pm 0.84^{\mathrm{b}}$ & $89.0 \pm 0.98^{\mathrm{ab}}$ & $88.1 \pm 1.07^{\mathrm{ab}}$ & $89.8 \pm 0.86^{\mathrm{a}}$ \\
Crude fibre & $72.8 \pm 0.82^{\mathrm{b}}$ & $78.0 \pm 0.62^{\mathrm{ab}}$ & $79.2 \pm 0.38^{\mathrm{a}}$ & $79.9 \pm 0.58^{\mathrm{a}}$ \\
Ether extract & $89.6 \pm 0.12$ & $89.0 \pm 0.84$ & $89.6 \pm 1.00$ & $89.0 \pm 0.96$ \\
Starch & $78.2 \pm 0.86^{\mathrm{a}}$ & $77.4 \pm 0.90^{\mathrm{ab}}$ & $77.1+0.98^{\mathrm{ab}}$ & $75.7 \pm 0.76^{\mathrm{c}}$ \\
Gross energy & $86.7 \pm 1.02^{\mathrm{a}}$ & $86.7 \pm 0.43^{\mathrm{n}}$ & $74.2 \pm 0.13^{\mathrm{b}}$ & $64.1 \pm 0.89^{\mathrm{b}}$ \\
\hline
\end{tabular}

$a, b, c \quad P<0.05$

The concentrations of blood urea-N and glucose obtained in this trial (Table 4) are slightly higher than the values reported earlier (Aregheore, 1996) for goats and the differences may be attributed to the diets. The concentrations of plasma urea-N and serum glucose obtained in goats fed the different diets indicated that the diets were adequate in protein and readily available energy, and that these were efficiently utilized by the goats for growth.

Dry matter, starch and gross energy were better digested $(\mathrm{P}<0.05)$ in diet $1(0 \%$ plantain peels), crude protein and crude fibre worse $(\mathrm{P}<0.05)$ than in the other diets (Table 5). The differences obtained between diets 1 and the others in the digestion of nutrients may be due to the levels of nutrients present in maize and plantain peels (Table 1) and subsequently in the diets (Table 3 ). The differences in gross energy and starch digestibility may be due to the fact that the starch in DMRPP was converted to sugars and this therefore resulted in loss in the digestibility of energy. The amount of starch in the different diets may have been responsible for the variations obtained in the level of serum glucose of the goats. Nutrients digestibility in this trial were higher than the values reported for other crop residue rations (Aregheore, 1995, 1996).

Compared to diet 1 , the percentage cost $/ \mathrm{kg}$ of concentrate diet and cost $/ \mathrm{kg}$ liveweight gains were 100,34,31 and 29;100,94, 91 and 82 for diets 1, 2, 3 and 4, respectively. The DMRPP diets were more economical than the control diet.

In conclusion, the results of this trial indicated that DMRPP is acceptable to goats, and it can substitute partially or totally the maize in concentrate supplements for goats without adverse effects on their performance. Cost of production was reduced with substitution of maize with DMRPP in the diets. Finally, data on performance characteristics, blood indices, nutrients digestibility and economics of production, demonstrated the nutritional significance of plantain peels as a feed in ruminant nutrition and that DMRPP can be effectively used to replace maize at a level of $80 \%$ in the concentrate supplements for goats. 


\section{ACKNOWLEDGEMENTS}

The author is grateful to the Nigerian Agricultural and Co-operative Bank, Warri Office, Warri, Delta State, Nigeria for the small ruminant loan that made this research possible and also to Messrs. Robert Aregheore and Sonny Onakpoma for care of the animals and for secretarial assistance, respectively.

\section{REFERENCES}

AOAC, 1980. Official Methods for Analysis. Association of Agricultural Chemists. Washington, DC, pp. 1094

Ankrah E.K., 1974. Chemical studies of some plant wastes from Ghana. J. Sci. Food Agric. 25, $1229-1232$

Aregheore E.M., 1994. Production and Management of Cattle, Goats and Sheep. COEWA Publishers, Warri, Nigeria, pp. 87

Aregheore E.M., 1995. Effect of sex on growth rate, voluntary feed intake and nutrient digestibility of West African Dwarf goats. Small Ruminant Res. 15, 217-221

Aregheore E.M., 1996. Voluntary intake and nutrient digestibility of crop residues based rations by goats and sheep. Small Ruminant Res. 22, 7-12

Aregheore E.M., Aluyi H.S.A., 1989 Studies on cassava flour and plantain peels as carbohydrate and energy sources in the diets of growing lambs. J. Exp. Appl. Biol. 2, 56-69

Aregheore E.M., Makayi R, Lungu J.C.N., 1994. Nutritive value of dried citrus pulp meal as feed ingredient in broiler finisher dicts in Zambia. Afr. J. Agric. Sci. 21 (2) (in press)

Crampton E.W., 1956. Applied Animal Nutrition. The Use of Feedstuffs in the Formulation of Livestock Rations. Bailey Brothers and Swinfen Limited, London, pp.458

Ffoulkes D., Espejo S., Marie O., Delpeche M., Preston T.R., 1978. The banana plant as cattle feed. Composition and biomass production. Trop. Anim. Prod. 3, 45-50

Geoffrey F., Despois P., 1978. Value of banana leaves and stem as forage: Utilization by animals and level of intake. Angro. Antilles, Guyana 4, 81-85

Gentzkow C.J., Masen M.J., 1942. An accurate method for the determination of blood urea nitrogen by direct Nesslerization. J. Biochem. 36, 145-530

Gills J.L., 1978. Design and Analysis of Experiments. Vol. 1. Iowa State University Press, Ames, 10

Ketiku A.O., 1973. Chemical composition of unripe (Green) and ripe plantain (Musa paradisiaca). J. Sci. Food Agric. 24, 703-707

MacRae J.C., Armstrong D.G., 1968. Methods for the estimation of starch. Analytical procedure for determination of $\alpha$-lined glucose polymer. J. Sci. Food Agric. 19, 578-581

McCullough T.A., 1970. A study of the effect of supplementing a concentrate diet with roughages of different quality on the performance of Friesian steers. I. Voluntary feed intake and food utilization. J. Agric. Sci., Camb. 75, 327-335

Montgomery M.J., Baumgardt B.R., 1965. Regulation of food intake in ruminants. 1. Pelleted rations varying in energy concentration. J. Dairy Sci. 48, 569-574

Ohide F., Becker K., Pfeffer E., 1979. Studies on the use of banana plant in ruminant feeding. Anim. Res. Develop. 10, 83-92

Oyenuga V.A., 1968. Nigeria's Food and Feedingstuffs: Their Chemistry and Nutritive Valuc. Ibadan University Press, Ibadan, pp. 99 
Pezo D., Fanola A., 1980. Chemical composition and in vitro digestibility of pseudostem and leaves of banana. Tropical Anim. Prod. 5, 81-86

Poyyamozhi V.S., Kadirvel R., 1986. The value of banana stalk as a feed for goats. Anim. Feed Sci. Technol. 15, 95-100

Sigma Technical Bulletin, No 115, 1976. Glucose in Serum or Plasma at 520nM. Sigma Chem. Co. St. Loius, Missouri, USA

Steel R.G.D., Torrie J.H., 1980. Principles and Procedures of Statistics. 2nd Edition. McGraw Hill. New York, NY, pp. 481

Swennen R., 1990. Plantain Cultivation under West African Conditions. A Reference Manual, IITA. Ibadan, pp. 24

Subramanian P.R., Kadirvel R., Viswanathan K., Chandrasekara D., 1988. In vitro studies and short-term feeding trial in lambs to evaluate plantain sheath (Musa sapientum) as a feed for ruminants. Anim. Feed Sci. Technol. 20, 343-348

Williamson G., Payne W.J.A.. 1978. An Introduction to Animal Husbandry in the Tropics. 3rd Edition. English Language Book Series. Longman, London, pp. 463-484

\section{STRESZCZENIE}

\section{Wartość pokarmowa suszonych dojrzalych skórek bananowea jako zamiennika kukury- dzy w żywieniu kóz}

Dwadzieścia cztery wschodnio-afrykańskie kozy karłowe o średniej masie ciała $12,88 \pm 0,08 \mathrm{~kg}$, 9-12 miesięczne, podzielono losowo na 4 grupy po 6 zwierząt każda 7 uwzględnieniem płci i wagi.

Skórkami bananowca zastąpiono kukurydzę w paszy treściwej w ilości $0,60,80$ i 100\% i podawano do woli przez $84 \mathrm{dni}$. Dowolne pobranie paszy treściwej zmniejszało się liniowo, lecz. nieistotnie $(\mathrm{P}>0,05)$, w miarę zwiększania się skórek bananowca w dawce. Pobranie paszy objętościowej było podobne we wszystkich grupach. Przyrosty dzienne masy ciała były większe $(\mathrm{P}<0,05)$ u kóz otrzymujących 60 i $80 \%$ skórek bananowca i wynosiły po 73 i 74 g, odpowiednio, w porównaniu z 70 i $68 \mathrm{~g} \mathrm{dziennie} \mathrm{w} \mathrm{grupach} \mathrm{otrzymujących} 0$ i $100 \%$ skórek. Różnice w przyrostach miçdzy grupą $1(\%)$ a $4(100 \%)$ nie były istotne. Sucha masa, skrobia i energia dawki I były lepiej trawione $(\mathrm{P}<0,05)$, a białko ogólne i włókno gorzej $(\mathrm{P}<0,05)$ niż pozostałych dawek. Koszt $\mathrm{kg}$ dawki oraz przyrostu masy ciała obniżały się $\mathrm{w}$ miarę obniżania się udziału skórek bananowea w paszy.

Wyniki doświadczenia wskazują, że wysuszone skórki bananowca mogą zastępować kukurydzę w żywieniu kóz bez ujemnego wpływu na wzrost i wyniki produkcyjne. Są one takźe tanim źródłem węglowodanów dla kóz. 